\title{
Sediment Delivery across Multiple Spatio-temporal Scales in an Agriculture Watershed of the Chinese Loess Plateau
}

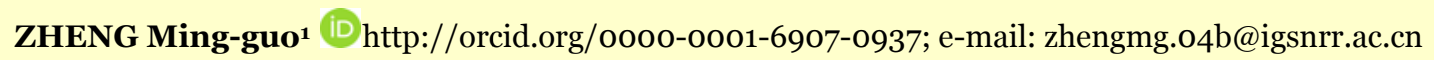 \\ LI Run-kui ${ }^{2}$ D http://orcid.org/oooo-ooo2-5822-5072; e-mail: lirk@ucas.ac.cn

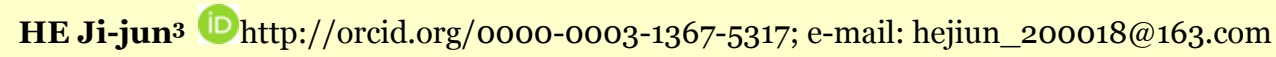

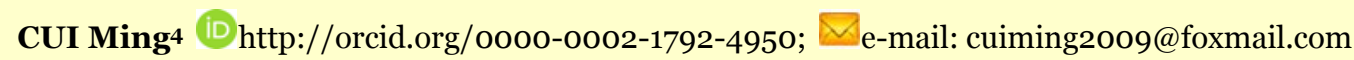 \\ 1 Key Laboratory of Water Cycle and Related Land Surface Processes, Institute of Geographic Sciences \& Natural Resources \\ Research, Chinese Academic of Sciences, Beijing 100101, China \\ 2 College of Resources and Environment, University of Chinese Academy of Sciences, Beijing 10oo49, China \\ 3 Base of the State Laboratory of Urban Environmental Processes and Digital Modeling, Capital Normal University, Beijing \\ 10048, China \\ 4 Institute of Desertification Studies, Chinese Academy of Forestry, Beijing 10oog1, China
}

Citation: Zheng MG, Li RK, He JJ, Cui M (2015) Sediment delivery across multiple spatio-temporal scales in an agriculture watershed of the Chinese Loess Plateau. Journal of Mountain Science 12(5). DOI: 10.1007/s11629-014-3187-x

(C) Science Press and Institute of Mountain Hazards and Environment, CAS and Springer-Verlag Berlin Heidelberg 2015

\begin{abstract}
There is a consensus that sediment delivery ratio in the Chinese Loess Plateau is close to 1 at the inter-annual timescale. However, little information is available about the sediment delivery at finer timescales. We evaluated the sediment delivery from plots to watersheds at the event or intra-annual, annual, and inter-annual timescales within the Wudinghe river basin, a $30,261 \mathrm{~km}^{2}$ basin in the Loess Plateau. We calculated the ratio of sediment output to sediment input and presented the temporal change of the channel morphology to determine whether sediment deposition occurs. Although a single flood event frequently has a sediment yield exceeding $10,000 \mathrm{t} \mathrm{km}{ }^{-2}$, sediment deposition rarely occurs except during some small runoff events (sediment yield $<5000 \mathrm{t} \mathrm{km}^{-2}$ ) or dry years (sediment yield $<10$,000 $\mathrm{t} \mathrm{km}^{-2}$ ) when moving from slopes up to the main channels of the Wudinghe River. This observation suggests a sediment delivery ratio close to 1 even at the event or intra-annual and the annual timescales, but not necessarily at the interannual timescale. Such a high sediment delivery ratio can be related to hyper-concentrated flows, which have very strong sediment transport capacity even at
\end{abstract}

Received: 20 October 2014

Accepted: 13 May 2015 low flow strength. Because hyper-concentrated flows are well-developed in the whole Loess Plateau, a sediment delivery ratio close to 1 below the interannual timescale possibly remains true for other rivers in the Loess Plateau.

Keywords: Sediment delivery ratio; Spatial scale; Soil erosion; Sediment yield; Loess Plateau

\section{Introduction}

Soil erosion and sediment delivery are important environmental problems and have long been recognized as major concerns for sustainable development (Alatorre et al. 2010; Sadeghi et al. 2013). Generally, only a small fraction of eroded sediments will arrive at the basin outlet and be represented in the basin sediment yield (Walling 1983; Alatorre et al. 2010). A dimensionless variable, termed sediment delivery ratio (SDR), was often used to link on-site erosion with downstream sediment yield (Walling 1983; Lane et al. 1997; Lu et al. 2005; De Vent et al. 2007). SDR is most commonly defined as the ratio of 
sediment yield to gross erosion. Despite some criticism including practical difficulty in estimating gross erosion (e.g. Lane et al. 1997) and the conceptual validity (Parsons et al. 2006), SDR remains a practical approach for sediment load predictions at the watershed scale (Notebaert et al. 2009; Vigiak et al. 2011; Shi et al. 2013; Shi et al. 2014).

SDR closely depends on the spatial and temporal scales over which sediment yield and gross erosion are measured (Lu et al. 2005). It has been well known that SDR typically decreases with increasing basin size due to the gentle slope and the channel gradient and increasing opportunities for deposition associated with large basins (Walling 1983; Lu et al. 2005). Over millennial timescales, SDR should approach unity (Lu et al. 2005; De Vente et al. 2007). In contrast, values of SDR reported in contemporary literatures, most of which do not rely on actual empirical data but spatially distributed models to obtain gross erosion rates, range from less than 0.1 to almost 1 (Walling 1983). Research efforts are therefore needed to investigate SDR at various spatio-temporal scales.

The Chinese Loess Plateau, located in the middle Yellow River basin, suffers from a soil loss rate higher than $10,000 \mathrm{t} \mathrm{km}^{-2} \mathrm{a}^{-1}$ (Gong and Xiong 1980). Gong and Xiong (1979 and 1980) compared areal sediment yield of variable-sized basins in the Loess Plateau, finding that stream channels of various orders are essentially in equilibrium between aggradation and degradation; thus, they suggested a SDR very close to 1 at the inter-annual timescale. Hyper-concentrated flows are well developed in the Loess Plateau ( $\mathrm{Xu}$ 1999). The subsequent calculations by Mou and Meng (1982) demonstrated that almost all sediment loads (>95\%) are wash loads as a result of the combination of the strong capacity of hyperconcentrated flows to suspend coarse sediments (Pierson 2005) and the fine texture of the loess $\left(\mathrm{d}_{50}\right.$ $<0.05 \mathrm{~mm}$ ); this mechanism physically enables a SDR close to 1 . Since then, a SDR close to 1 across a wide range of basin sizes in the Loess Plateau at the inter-annual timescale has acquired broad acceptance (e.g., Cai 1998; Jing et al. 1993; Lu et al. 2005; Walling 1983 and 1999; Xu 1999; Xu and Sun 2004). Nevertheless, little information is available on sediment delivery below the interannual timescale. As with other regions around the world (Moliere et al. 2004; Shi et al. 2004; Marques et al. 2008; Angulo-Martínez and Beguería 2009), a small number of extremely intense rainfall events are typically responsible for the largest proportion of soil erosion and sediment delivery in the Loess Plateau. A single flood event, which frequently causes a soil loss exceeding $10,000 \mathrm{t} \mathrm{km}^{-2}$, can contribute up to $90 \%$ of the annual sediment yield (Gong 1988; Liu et al. 2013). Hence, there is a need to address the sediment delivery at the event timescale or other timescales finer than several years.

The object of this study is to evaluate the sediment delivery across a range of spatiotemporal scales in the Loess Plateau, with a special attention to the timescale allowing a SDR close to 1. Using observations at a series of nested sites, we evaluated the sediment delivery from plots to watersheds within the Wudinghe River basin (Figure 1), a tributary of the middle Yellow River, at the event or intra-annual, annual, and inter-annual timescales.

\section{Study Area and Data Source}

The Wudinghe River drains an area of 30,261 $\mathrm{km}^{2}$. The river runs across eolian sandy areas in its upper part and across loess areas in its lower part (Figure 1(a)). Typical of the hilly loess areas, the loess mantle in the lower part is generally thicker than $100 \mathrm{~m}$. Loess is loosely compacted and susceptible to water erosion. The climate is semiarid and temperate. Vegetation cover is sparse. Mean average annual precipitation is about 450 $\mathrm{mm}$ in the loess areas and decreases to $400 \mathrm{~mm}$ in the eolian sandy areas. The terrain in loess areas is very precipitous and deeply dissected. Stream channels deeply incise into bedrock. Mass wasting such as slumping, sliding and collapsing is active on valley side slopes. More details of the Wudinghe basin can be found in Xu (2011) and Li et al. (2007).

The Wudinghe basin has a long history (> 1000 years) of agriculture cultivation. Before 1970, the basin was intensively cultivated except steep areas. For instance, the percent area of the cultivated land was as high as $65 \%$, whereas the percent area of the land steeper than $20^{\circ}$ was as high as $68 \%$ in the $205 \mathrm{~km}^{2}$ Chabagou Creek, a second-order tributary of the Wudinghe River 


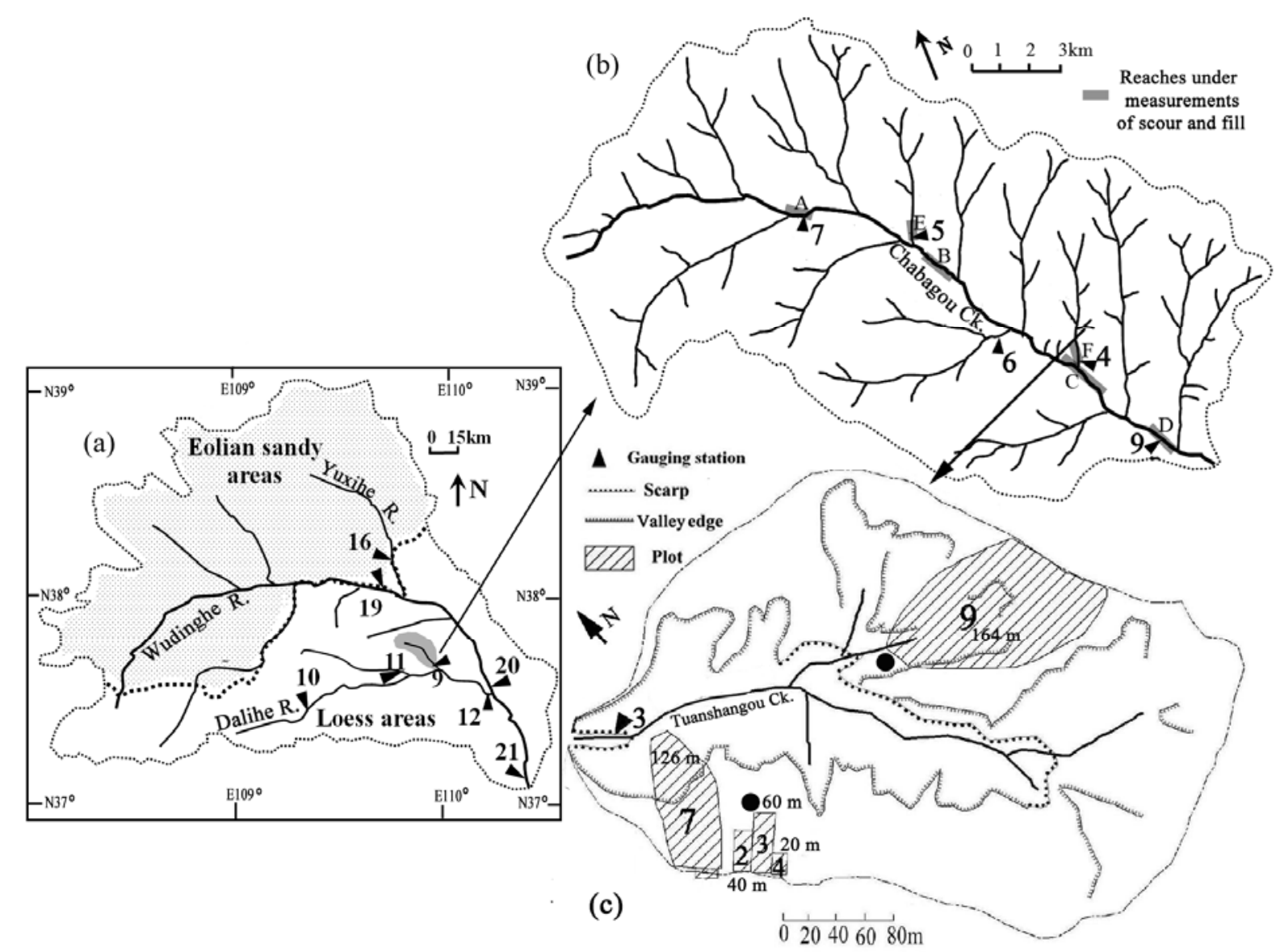

Figure 1 Locations of the study area and gauging stations: (a) the Wudinghe River, (b) the Chabagou Creek (modified from Zheng et al. (2011)), and (c) the Tuanshangou Creek (modified from Zheng et al. (2011)). The numbers for the gauging stations correspond to the station numbers in Table 1 . The Plot numbers in (c) correspond to those given in Table 2 in Zheng et al. (2012). Plot length was presented in (c). Letters in (b) correspond to the reach codes in Table 3.

(Figure 1(b)). Watershed management for soil conservation was not extensively implemented. In contrast, the basin was under intensive soil conservation after 1970; especially, a large number of hydrologic engineering works such as check dams intercepted large quantities of sediment. Hence, the post-1970 period was not considered in the present study. In addition, many experimental sites were not operated before 1959. As a result, we limited our analysis to the period 1959-1969. During this period, the observed sediment yield in the loess areas of the Wudinghe basin was as high as $19,000 \mathrm{t} \mathrm{km}^{-2} \mathrm{a}^{-1}$.

Unless stated otherwise, all data used in this study were obtained from the Yellow River Water Conservancy Commission (YRWCC). The YRWCC stream-gauging crews conducted all measurements following national standard procedures issued by the Ministry of Water Resources of the PRC (1962). The procedures are essentially identical to the international procedures (Xu and Yan 2005). See Zheng et al. (2012) and Zheng et al. (2013) for details of the measurement procedures.

The sediment yield data we used involve three timescales: sediment yield per unit area for a single event $\left(S S Y_{\mathrm{e}}, \mathrm{t} \mathrm{km}{ }^{-2}\right)$, sediment yield per unit area for a single year $\left(S S Y_{\mathrm{a}}, \mathrm{t} \mathrm{km} \mathrm{km}^{-2}\right)$, and the mean annual sediment yield per unit area $\left(S S Y, \mathrm{t} \mathrm{km}^{-2}\right.$ $\left.\mathrm{a}^{-1}\right) . S S Y$ is the arithmetic mean of $S S Y_{\text {a. }}$. Sediment delivery pathways include both stream channels and upland slopes. Deposition whether on slopes or along stream channels would lead to a SDR smaller than 1. Hence, the evaluation of SDR should consider processes both on slopes and along stream channels. Observations at 13 gauging stations (Table 1) and 5 runoff experimental plots 


\begin{tabular}{llll}
$\begin{array}{l}\text { Table } 1 \text { Gauging stations or experimental watersheds } \\
\text { in the Wudinghe basin }\end{array}$ & $\begin{array}{l}\text { Stations or } \\
\text { watershed a }\end{array}$ & $\begin{array}{l}\text { Area } \\
\text { (km) }\end{array}$ & $\begin{array}{l}\text { SSY b } \\
\left.\text { (t km-2 } \mathbf{~ a}^{-1}\right)\end{array}$ \\
\hline Tuanshangou & Tuanshangou (\#3) & 0.18 & 19,751 \\
Shejiagou & Shejiagou (\#4) & 4.26 & 16,937 \\
Tuoerxianggou & Tuoerxianggou (\#5) & $5 \cdot 74$ & 14,628 \\
Liujiagou & Sanchuankou (\#6) & 21 & 16,948 \\
Chabagou & Xizhuang (\#7) & 49 & 21,977 \\
Chabagou & Caoping (\#9) & 187 & 21,763 \\
Dalihe & Qingyangcha (\#10) & 662 & 16,001 \\
Xiaolihe & Lijiahe (\#11) & 807 & 15,784 \\
Dalihe & Suide (\#12) & 3893 & 16,680 \\
Yuxihe & Yulin(\#16) & 4938 & 846 \\
Wudinghe & Zhaoshiyao(\#19) & 15,325 & 2152 \\
Wudinghe & Dingjiagou(\#20) & 23,422 & 3711 \\
Wudinghe & Chuankou(\#21) & 30,217 & 6945 \\
Wudinghe & IR\#3 & 9355 & 19,341 \\
\hline
\end{tabular}

Notes: a The numbers in parentheses correspond to the station numbers given in Figure 1 . IR\# 3 denotes the reach between station \#21 and the confluence of the Yuxihe River into the Wudinghe River (See Figure 1(a)).

${ }^{\mathrm{b}} S S Y$ involves the period 1959-1969.

were used. The watersheds upstream of the gauging stations have areas ranging between 0.18 and $30,217 \mathrm{~km}^{2}$. The number of the $S S Y_{\mathrm{a}}$ data for a gauging station varied from 8 to 11, with a mean of 10.3 over the period 1959-1969. The experimental plots we used are all located in the Tuanshangou sub-watershed (Figure 1(c)), a headwater basin in the Chabagou watershed. The plots were all used as farmland and had a length varying from 20 to 164 $\mathrm{m}$ (Figure 1(c)). The number of recorded events ranged from 36 to 58 over the monitoring period 1961-1969. Detailed information is available in Table 2 of Zheng et al. (2012). Whether land use or topography of these plots were typical of the loss area of the Wudinghe basin.

It should be noted that the observed sediment load includes both suspended and bed loads on slopes but only the suspended load for watersheds. In the subsequent text, the term sediment yield refers to the total load for plots and the suspended load for watersheds. As mentioned above, however, the calculation by Mou and Meng (1982) demonstrated that almost all sediment loads
(>95\%) are wash loads in the Loess Plateau. For this reason, the measured sediment load can be regarded as the total load from plots to watersheds.

\section{Methods}

Following Wischmeier and Smith (1978), this study defined the gross erosion to include all eroded sediments both on slopes and within or along stream channels. It should be noted that mass-wasting materials should not be included into the gross erosion unless they are dislodged into flows. Such a definition implies that SDR can never exceed 1 and a SDR of 1 is simply identical to no deposition loss. We used the ratio of sediment output to sediment input to determine whether deposition loss occurs. Gross erosion is the summation of erosion from all sources within the watershed, whereas sediment input into a river reach includes both what is delivered from its upper reach plus the contributions from the tributaries. Deposition occurs if the ratio is smaller than 1, whereas sediment entrainment occurs if the ratio is larger than 1. For a river basin, SDR is not equal to 1 unless the ratio is consistently larger than or equal to 1 from upland slopes up to the main stream.

Corresponding to the three timescales we examined, we calculated the ratio of sediment output to sediment input for a single event $\left(R_{\mathrm{e}}\right)$, for a single year $\left(R_{\mathrm{a}}\right)$, and for the whole period 1959$1969(R)$. The calculations involve five spatial scales: slopes (up to $0.0172 \mathrm{~km}^{2}$ ), the Tuanshangou Creek (Figure 1(c), $0.18 \mathrm{~km}^{2}$ ), the Chabagou Creek (Figure 1(b), $205 \mathrm{~km}^{2}$ ), the Dalihe River (Figure 1(a), $3906 \mathrm{~km}^{2}$ ), and the reach between station \#21 and the confluence of the Yuxihe River into the Wudinghe River (Figure 1(a), $9355 \mathrm{~km}^{2}$ ), i.e. the IR\#3 Reach in Table 1. The IR\# 3 Reach drains an area comprising the major part of the loess areas in the Wudinghe basin. The reach upstream of the IR\#3 reach primarily passes through eolian sandy areas.

Table 2 presents all equations for calculating $R_{\mathrm{e}}, R_{\mathrm{a}}$, and $R$. On slopes, we used the observed sediment yield at longer plots as the sediment 
Table 2 Calculations of $R_{\mathbf{e}}, R_{\mathbf{a}}$ and $R^{\text {a }}$

\begin{tabular}{|c|c|c|c|}
\hline Site & $\boldsymbol{R}_{\mathbf{e}}$ & $\boldsymbol{R}_{\mathbf{a}}$ & $\boldsymbol{R}$ \\
\hline Plot $2^{\mathbf{b}}$ & $S S Y_{\mathrm{ep} 2} / S S Y_{\mathrm{ep} 4}$ & $S S Y_{\text {ap2 }} / S S Y_{\text {ap4 }}$ & $S S Y_{\mathrm{p} 2} / S S Y_{\mathrm{p} 4}$ \\
\hline Plot $3^{\mathbf{b}}$ & $S S Y_{\text {ер3 }} / S S Y_{\text {ep2 }}$ & $S S Y_{\text {ap3 }} / S S Y_{\text {ap2 }}$ & $S S Y_{\mathrm{p} 3} / S S Y_{\mathrm{p} 2}$ \\
\hline Plot $7^{\mathbf{b}}$ & $S S Y_{\text {ep7 }} / S S Y_{\text {eр3 }}$ & $S S Y_{\text {ap7 }} / S S Y_{\text {ap3 }}$ & $S S Y_{\mathrm{p} 7} / S S Y_{\mathrm{p} 3}$ \\
\hline \multirow[b]{2}{*}{ Tuanshangou $\mathbf{c}^{\mathbf{c}}$} & $S S Y_{\mathrm{e} 3}$ & $S S Y_{\text {аз }}$ & $\mathrm{SSY}_{3}$ \\
\hline & $\overline{\frac{1}{2}\left(S S Y_{\mathrm{ep} 7+} S S Y_{\mathrm{ep} 9}\right)}$ & $\overline{\frac{1}{2}\left(S S Y_{\left.\text {ap } 7+S S Y_{\text {ap } 9}\right)}\right.}$ & $\overline{\frac{1}{2}\left(S S Y_{\mathrm{p} 7}+S S Y_{\mathrm{p} 9}\right)}$ \\
\hline Chabagou $\mathbf{c}$ & $-\mathrm{d}$ & $S S Y_{\mathrm{a} 9} / \frac{1}{4} \sum_{i=4}^{7} S S Y_{\mathrm{a} i}$ & $S S Y_{9} / \frac{1}{4} \sum_{i=4}^{7} S S Y_{i}$ \\
\hline Dalihe $\mathbf{c}^{\mathbf{c}}$ & $-d$ & $S S Y_{\mathrm{a} 12} / \frac{1}{2} \sum_{i=10}^{11} S S Y_{\mathrm{a} i}$ & $S S Y_{12} / \frac{1}{2} \sum_{i=10}^{11} S S Y_{i}$ \\
\hline \multirow{2}{*}{$\mathrm{IR} \# 3^{\mathrm{c}}$} & $-d$ & $S S Y_{\text {a21 }} A_{21}$ & $S S Y_{21} A_{21}$ \\
\hline & & $\overline{\left(S S Y_{\mathrm{a} 16} A_{16}+S S Y_{\mathrm{a} 19} A_{19}+S S Y_{\mathrm{a} 12} A_{\mathrm{IR} \# 3)}\right)}$ & $\overline{\left(S S Y_{16} A_{16}+S S Y_{19} A_{19}+S S Y_{12} A_{\mathrm{IR} \# 3}\right)}$ \\
\hline
\end{tabular}

Notes: a $R_{\mathrm{e}}, R_{\mathrm{a}}$ and $R$ represents the ratio between sediment output and sediment input at the event, annual and inter-annual timescales, respectively.

b Plot length increases in an order of Plots 4, 2, 3 and 7 (Figure 1 (c)). SSY epi and $S S Y_{\text {api }}$ represent the erosion intensity $\left(\mathrm{t} \mathrm{km}^{-2}\right)$ at Plot $i$ for a specific event and for a specific year, respectively. $S S Y_{\text {pi }}$ represent the mean annual erosion intensity $\left(\mathrm{t} \mathrm{km}^{-2} \mathrm{a}^{-1}\right)$ at Plot $i$ for the period 1959-1969.

c $S S Y_{\mathrm{e} i}$ and $S S Y_{\mathrm{a} i}$ represent areal sediment yield observed at station $\# i$ for a specific event and for a specific year (t $\left.\mathrm{km}^{-2}\right)$, respectively. $S S Y_{i}$ represents areal sediment yield observed at station \# $i$ for the period $1959-1969\left(\mathrm{t} \mathrm{km}{ }^{-2} \mathrm{a}^{-1}\right)$. $A_{19}$ and $A_{21}$ represent the drainage area upstream of stations \#19 and \#21, respectively. $A_{16}$ represents the drainage area of the Yuxihe River (Figure $1(\mathrm{a})$ ), and $A_{\mathrm{IR} \# 3}$ represents the drainage area between station \#21 and the confluence of the Yuxihe River into the Wudinghe River.

${ }^{\mathrm{d}}$ High spatially variability in rainfall prevents us from estimating $R_{\mathrm{e}}$ accurately when the basin size increases. Instead, we used the direct measurements of scour and fill along the stream channels in the Chabagou watershed (see Figure 4), and the temporal change of channel cross-section profiles of the Dalihe river and the Wudinghe river (see Figure 5), to evaluate whether downstream deposition occurs or not at the intra-annual timescale.

output, and that at shorter plots as the sediment input. Plots 7 and 9 are composed of two parts of hillslope and valley side slope. Such large-sized plots are termed as the entire slope in Chinese literatures. Permanent, incised gullies are developed at valley side slopes, allowing overland flows directly draining into the creek. Hence, we used observations at Plots 7 and 9 to calculate the sediment input into the Tuanshangou Creek. Comparisons of $S S Y_{\mathrm{e}}$ of Plots 7 and 9 on the same rainfall day returns a linear equation with a regression coefficient close to 1 (0.94) and a $R^{2}$ of 0.93, indicating that $S S Y_{\mathrm{e}}$ should be fairly uniform among entire slopes of the Tuanshangou subwatershed. Hence, we believe that the sediment input into the creek can be effectively estimated using observations at Plots 7 and 9 though they only account for $12.7 \%$ of the whole drainage area of the Tuanshangou Creek.

For rivers, we used the sediment yield observed at the most downstream station as the sediment output, and used the sediment yields observed at upstream stations plus that observed in tributaries to estimate the sediment input. We intentionally selected the tributaries in various parts of the river. Relatively small tributaries were excluded because they tend to be greatly affected by local extreme events. The total area upstream of the selected stations used for calculating the sediment input compose $42.8 \%$ and $37.7 \%$ of the total drainage areas of the Chabagou Creek and the Dalihe River, respectively. The upstream area of station \#12, the most downstream station of the Dalihe River, accounts for $41.6 \%$ of the drainage area of the IR\#3 Reach. Hence, we directly used the observations at station $\# 12$ as the sediment input per unit area from the tributaries into the IR\#3 Reach. Physiographic properties, such as soil, topography, vegetation and the processes of erosion and sediment delivery, are fairly uniform in space over the hilly loess areas (Wang et al. 1982). Hence, we believe such estimations are reasonable 
approximations.

In the Loess Plateau, rainstorms typically cover a small area of less than $10 \mathrm{~km}^{2}$ (Zhang 1983). In this case, the observed difference in $S S Y_{\mathrm{e}}$ may be simply a result of spatially uneven rainfall distribution. For this reason, we do not calculate $R_{\mathrm{e}}$ for the Chabagou Creek, the Dalihe River and the IR\#3 Reach. Instead, we used the measurements of the channel morphology, including direct measurements of scour and fill and the temporal change of channel cross-section profiles, to evaluate the scour and fill at the intra-annual timescale. The measurements of scour and fill were made at six reaches within the Chabagou watershed. The reaches, four along the main stream and two along the tributaries of the Chabagou Creek (see Figure 1(b)), cover a length between 80 and $600 \mathrm{~m}$ (Table 3). The measurements along every reach were made at 5-14 cross sections with an interval between 20 and 50 $m$ every one or several flood events. The height measurement was made using the level instrument with a maximum allowed discrepancy between forward and backward levelling of $\pm 30 \sqrt{L} \mathrm{~mm}$, where $L(\mathrm{~km})$ is the length of the levelled segment. By comparing with the last measurement, the depth of scour or fill at a cross section between two measurements was determined. The depth of scour or fill for a whole reach was then determined using the distance between the cross sections as the weight factor.

\section{Results}

\subsection{The event or intra-annual timescale}

As shown in Figure 2, $R_{\mathrm{e}}$ is larger than or close to 1 on slopes for major sediment-producing events $\left(S S Y_{\mathrm{e}}>5000 \mathrm{t} \mathrm{km}-2\right) . R_{\mathrm{e}}$ is significantly smaller than 1 only in case of small events. The same holds for the Tuanshangou Creek (Figure 3), suggesting that sediment deposition rarely occurs except during some small runoff events when moving

Table 3 Reaches under measurements of scour and fill

\begin{tabular}{lllllllll}
$\begin{array}{l}\text { Reach } \\
\text { Code }\end{array}$ & Creek & $\begin{array}{l}\text { Monitoring } \\
\text { period }\end{array}$ & $\mathbf{A}^{\mathbf{b}}\left(\mathbf{k m}^{\mathbf{2}}\right)$ & $\mathbf{L}^{\mathbf{b}}(\mathbf{m})$ & $\mathbf{W}^{\mathbf{b}} \mathbf{( m )}$ & $\mathbf{n}^{\mathbf{b}}$ & $\mathbf{d}^{\mathbf{b}}(\mathbf{m})$ & $\begin{array}{l}\text { Channel } \\
\text { form }\end{array}$ \\
\hline A & Chabagou & $1963-1966$ & 49 & 125 & 32 & 6 & 25 & Sinuous \\
B & Chabagou & $1963-1966$ & 96.1 & 200 & 64 & 5 & 50 & Straight \\
C & Chabagou & $1963-1966$ & 151 & 600 & 106 & 14 & 46 & Sinuous \\
D & Chabagou & $1963-1966$ & 187 & 300 & 60 & 7 & 50 & Straight \\
E & Tuoerxiang & $1963-1966$ & 5.74 & 80 & 22 & 5 & 20 & Straight \\
F & Shejiagou & $1963-1966$ & 4.26 & 162 & 17 & 5 & 41 & Straight \\
\hline
\end{tabular}

Notes: ${ }^{a}$ The reach codes correspond to those given in Figure 1 (b).

${ }^{b}$ A: Upstream area; L: length of the examined reach; W: Mean channel width; n: Number of the cross section under measurement; $d$ : mean distance between two neighboring cross sections; $d=L /(n-1)$.
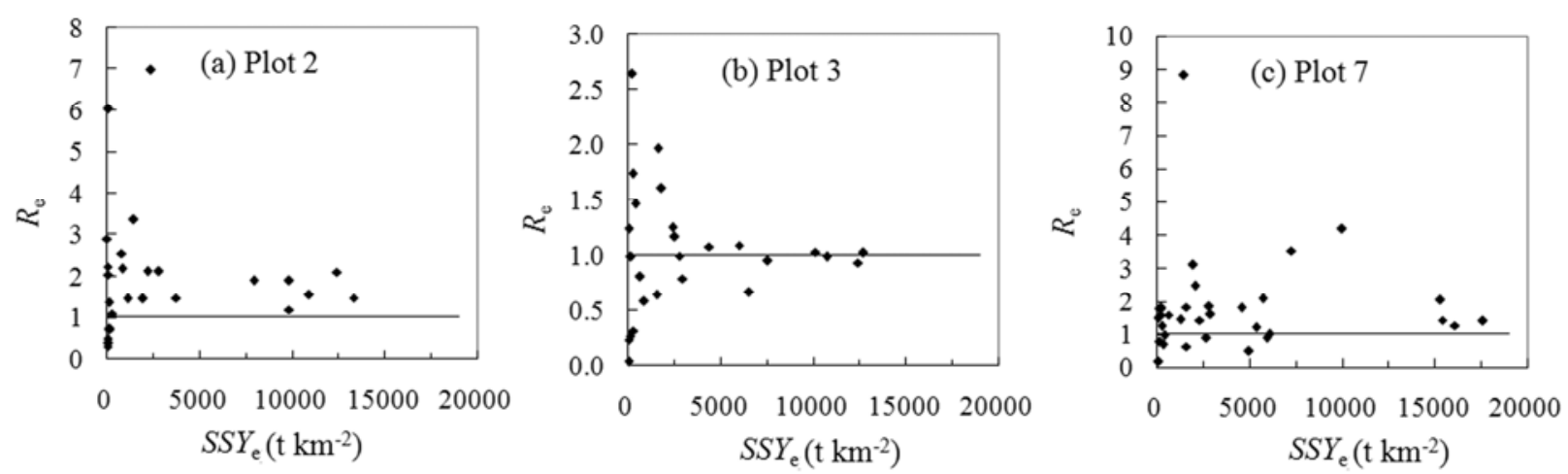

Figure $2 R_{\mathrm{e}}$ on slopes, indicating whether downslope deposition occurs during runoff events (deposition occurs if $\left.R_{e}<1\right)$. 


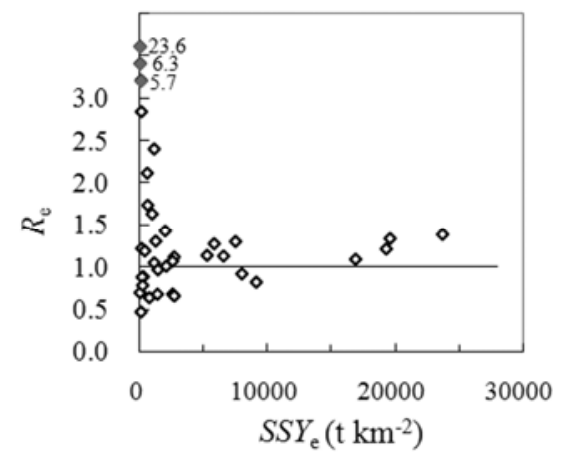

Figure $3 R_{\mathrm{e}}$ for the Tuanshangou Creek $\left(0.18 \mathrm{~km}^{2}\right)$, indicating channel degradation or aggradation for single flood events (deposition occurs if $R_{e}<1$ ). Three events had a markedly large $R_{\mathrm{e}}(>3)$, so that they are presented using solid rhombuses with a given number representing the true value.

from slopes to the Tuanshangou Creek.

Figure 4 shows that single flood events, many of which had a $S S Y_{\mathrm{e}}$ larger than $10,000 \mathrm{t} \mathrm{km}^{-2}$, primarily cause a depth of scour or fill less than $5 \mathrm{~cm}$ whether along the tributaries or along the main stream of the Chabagou Creek. By contrast, our calculation shows that a $10 \%$ deposition loss would even lead to a net aggradation of $7.7 \mathrm{~cm}$ on average along the whole main stream of the Chabagou Creek in case of a moderate flood event having a $S S Y_{\mathrm{e}}$ of $5000 \mathrm{t} \mathrm{km}^{-2}$, given a mean channel width of $40 \mathrm{~m}$ (the channel width at the middle Chabagou Creek) and a specific weight of $1.4 \mathrm{~g} \mathrm{~cm}^{-3}$ for the deposition materials (Chien 1989). Hence, it can hardly be expected that significant channel scour or fill would accompany a single flood event in the $205 \mathrm{~km}^{2}$ Chabagou watershed.

As shown in Figure 5, a similar observation holds for the Dalihe River and the Wudinghe River. A 10\% deposition loss along the main stream of the Dalihe River would allow a net aggradation of 18 $\mathrm{cm}$ given a $S S Y_{\mathrm{e}}$ of $5000 \mathrm{t} \mathrm{km}^{-2}$ (using the channel width in the middle reach, $50 \mathrm{~m}$, to be the mean width). The equivalent value increases up to $50 \mathrm{~cm}$ for the IR\#3 Reach of the Wudinghe River (using the channel width in the middle reach, $150 \mathrm{~m}$, to be the mean width). In the context of such a potential for enormous sediment storage, however, three cross-section profiles under examination, one of the Dalihe River (Figure 5(a)(c)) and two of the Wudinghe River (Figure 5(d)(h)), shows no signs of any deformation within a year. Both profiles of the Wudinghe River remained roughly unchanged before and after a flood season (May to September) even though the sediment yield over the flood season was up to 1.7 (Figure 5(g)) or 1.8 (Figure 5(e)) times as great as the long-term annual value. At the examined profile of the Dalihe River, channel aggradation only occurred during the flood event from Aug 27, 1967 to Sep 1, 1967 (Figure 5(c)), which recorded a $S S Y_{\mathrm{e}}$ of $5675 \mathrm{t} \mathrm{km}^{-2}$. Although the net aggradation
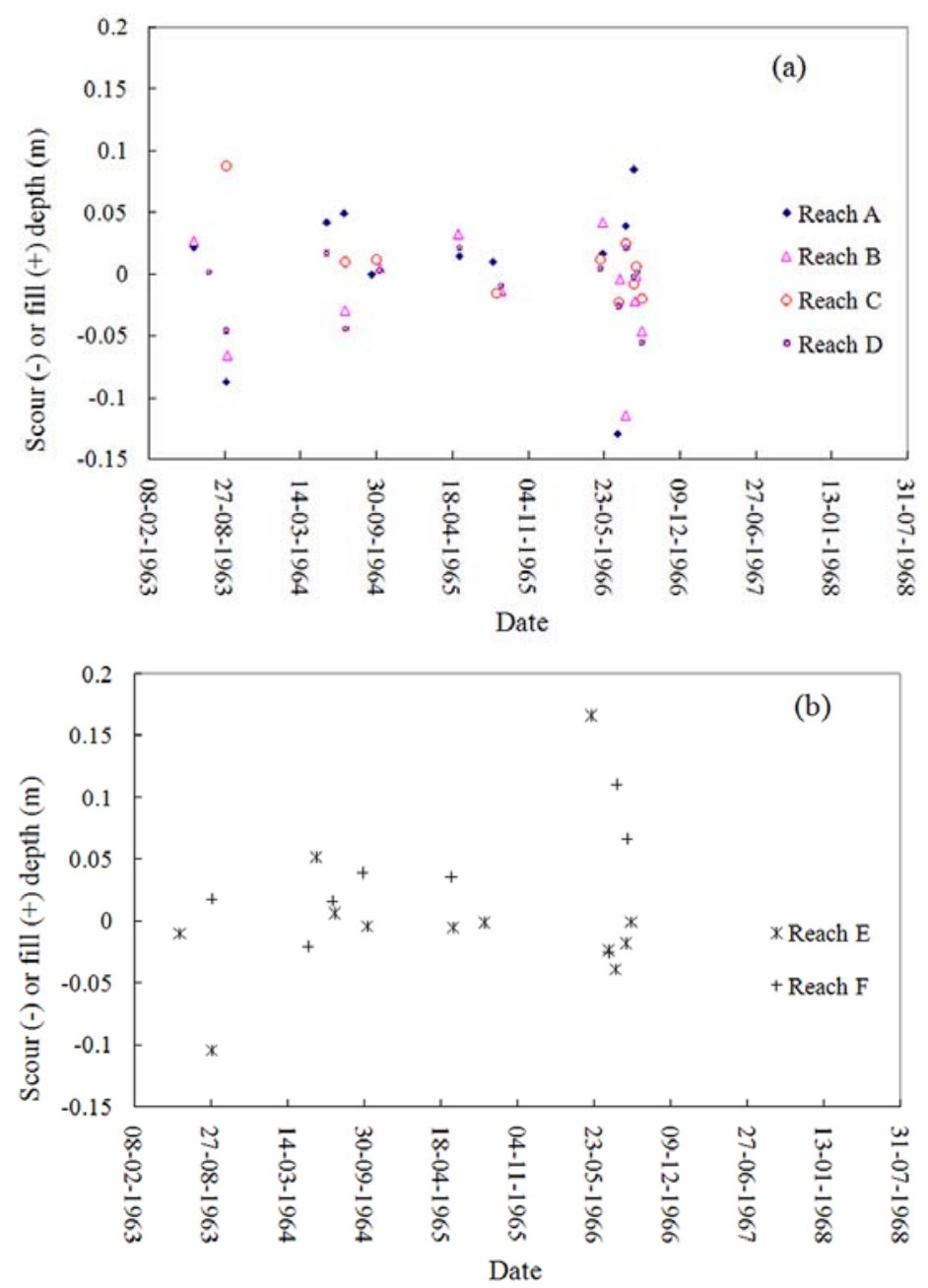

Figure 4 Depth of scour of fill relative to the last measure for (a) four reaches along the main stream, and (b) two reaches along the tributaries of the Chabagou Creek $\left(205 \mathrm{~km}^{2}\right)$, indicating channel degradation or channel aggradation at the intra-annual timescale. The reach locations are presented in Figure 1(b). The first measurement generally occurred in June 1963. 

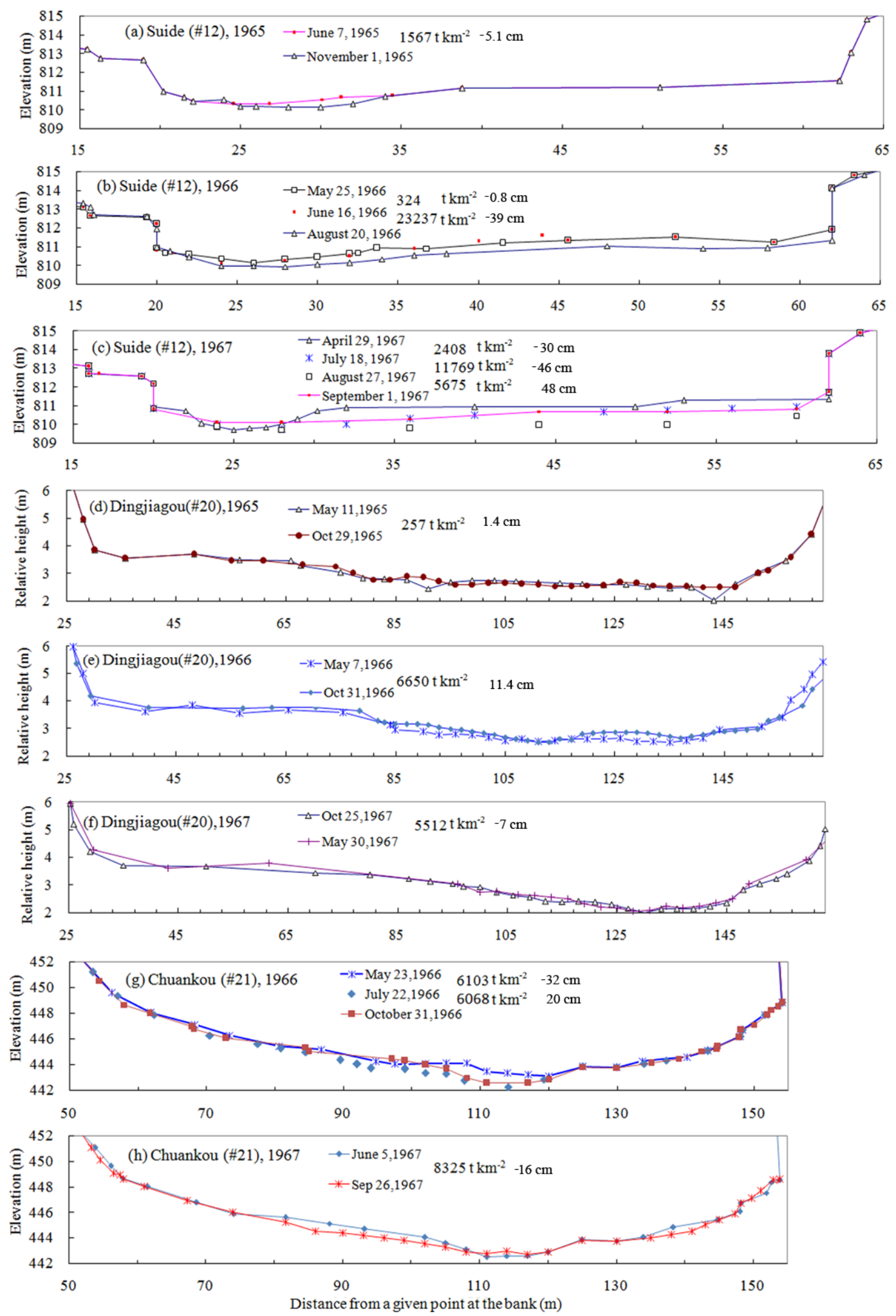

Figure 5 Temporal changes of the channel cross-section profiles at stations of \#12 (a)-(c), \#20 (d)-(f), and \#21 (g)-(h), indicating channel degradation or aggradation at the intra-annual timescale. The first and the last measurements are specially shown as lines for every year. The first measurement of the channel cross-section profiles generally occurred prior to a flood season, and the last occurred following the flood season. Areal sediment yield (in t km$~^{-2}$ ) and depth (in $\mathrm{cm}$ ) of scour (-) and fill (+) between two measurements are presented. Note that for a clear presentation, the vertical scale is intentionally set larger than the horizontal scale in (d)-(h). 
was nearly $50 \mathrm{~cm}$, it was equivalent to a downstream deposition ratio of $21 \%$. For two intraannual periods recording a sediment yield higher than $10,000 \mathrm{t} \mathrm{km}^{-2}$, channel degradation instead of channel aggradation occurred, with a scour depth of $39 \mathrm{~cm}$ (Figure 5 (b)) and $46 \mathrm{~cm}$ (Figure 5 (c)), respectively. Our calculations indicate that such degradations provided approximately 5\% and $11 \%$ of the total sediment yield respectively, suggesting a very limited contribution by recruitment of sediment within stream channels.

\subsection{The annual and inter-annual timescale}

As mentioned in the introduction section, the annual sediment yield in the loess areas is typically dominated by a small number of large flood events. For instance, the maximum $S S Y_{\text {a }}$ value was as high as 71,100 $\mathrm{t} \mathrm{km}^{-2}$ at station \#9 over the period 19591969. Although this value was about 3.3 times higher than the mean annual value, it was largely (about 95\%) produced by four single events in 1966. Because $R_{\mathrm{e}}$ is generally larger than 1 for major
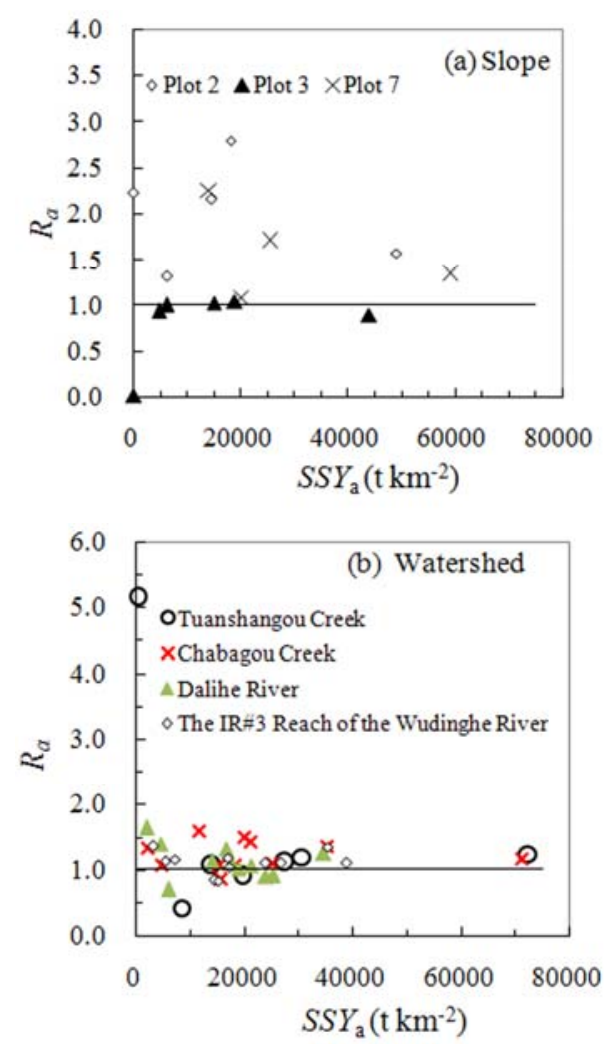

Figure $6 R_{\mathrm{a}}$ varying from slopes (a) to watersheds of various orders (b), indicating whether sediment deposition occurs at the annual timescale (deposition occurs if $R_{a}<1$ ). sediment-producing events, $R_{\mathrm{a}}$ remains larger than or close to 1 for major sediment-producing years $\left(S S Y_{\mathrm{a}}>10,000 \mathrm{t} \mathrm{km}^{-2}\right.$; Figure 6). Measurements of cross-section profiles of stream channels of various orders also suggest very limited downstream sediment storage at the annual timescale. As shown in Figures 7 and 8, the six examined profiles varied little between neighboring pre-flood seasons over the years $1965-1970$, with a depth of scour or fill primarily smaller than $10 \mathrm{~cm}$.

The long-term sediment yield is largely determined by major sediment-producing years. Our calculation indicates that the major sedimentproducing years contributed more than 90\% of the total sediment yield at all examined sites other than Plots 4 and 2. As a result, $R$ values we obtained are all larger than 1 from plots to watersheds (Figure 9). $R$ values at the watershed scales, ranging from 1.05 to 1.12 , are closer to 1 than $R_{\mathrm{a}}$ (Figure 6(b)); this observation indicate that the stream channels are in equilibrium between degradation and aggradation and the channel scour or fill has little effect on the long-term sediment yield.

\section{Discussion}

Except for some small events $\left(S S Y_{\mathrm{e}}<5000\right.$ $\left.\mathrm{t} \mathrm{\textrm {km } ^ { - 2 }}\right)$ or dry years $\left(S S Y_{\mathrm{a}}<10,000 \mathrm{t} \mathrm{km}^{-2}\right)$, we do not find any evidence for sediment storage from plots up to the main stream of the Wudinghe basin; this suggests a SDR approaching 1 at the event or intra-annual timescale and at the annual timescale, not necessarily at the inter-annual timescale, as is commonly perceived.

Responding to larger runoff-contributing areas, erosion intensity increases in the downslope direction. As a result, $R_{\mathrm{e}}, R_{\mathrm{a}}$ and $R$ are typical larger than 1 on slope lands (Figure 2, Figure 6(a) and Figure 9). The field survey (Gong and Xiong 1979 and 1980; $\mathrm{Xu}$ and Sun 2004) consistently suggested no significant deposition loss on slopes in the Wudinghe basin; this considerable lends support to our results, which are simply based on observations within one among numerous subwatersheds of the Wudinghe basin. The ${ }^{137 \mathrm{Cs}}$ measurements (Jing et al. 1997) in other river basins of the Loess Plateau also agree well with our results.

Wang et al. (1982) and Xu (2004) reported a 

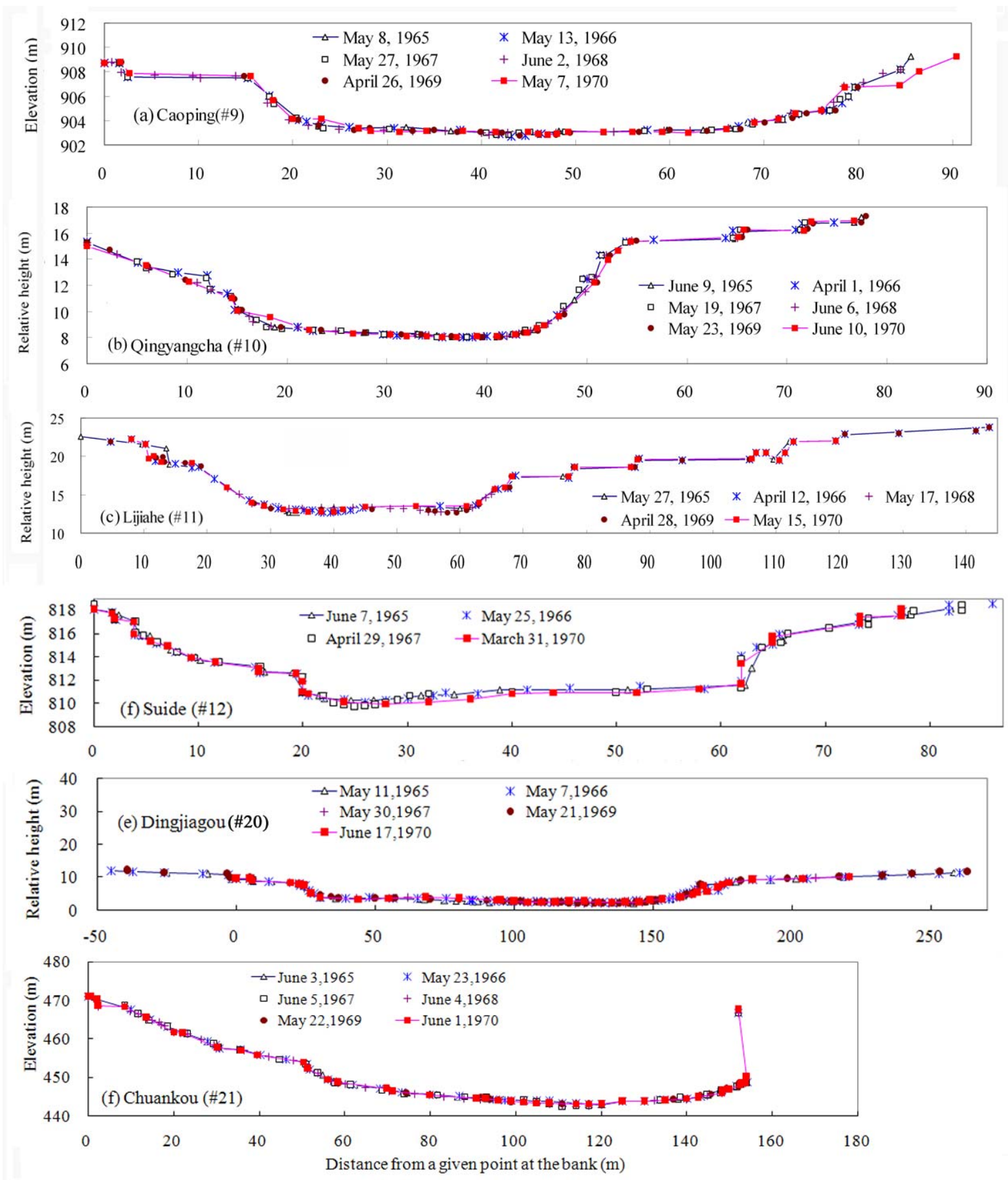

Figure 7 Temporal changes in six cross-section profiles of stream channels of various orders in the Wudinghe basin. Note that all profiles were measured before flood seasons for ensuring comparability.

sediment storing-releasing mechanism in the Chabagou Watershed. During small flow events or the recession stage of rainstorm floods, flows are incapable of conveying the relatively coarse fractions of suspended sediment and deposit them in channels. The subsequent flows incorporate these deposited sediments and release them from the channels. Both $R_{\mathrm{e}}$ in Figure 3 and $R_{\mathrm{a}}$ in Figure 6(b) falls within a narrow range for major sediment-producing events $\left(S S Y_{\mathrm{e}}>5000 \mathrm{t} \mathrm{km}{ }^{-2}\right)$ or years $\left(S S Y_{\mathrm{a}}>10,000 \mathrm{t} \mathrm{km}^{-2}\right)$, averaging 1.2 when $R_{\mathrm{e}}$ or $R_{\mathrm{a}}$ is larger than 1 ; this implies that the preevent sediment storage within channels contributes approximately $20 \%$ to $S S Y_{\mathrm{e}}$ and $S S Y_{\mathrm{a}}$. The direct 
measurements of scour and fill and the temporal change of channel cross-section profiles also do not suggest a remarkable channel scour whether at the intra-annual (Figures 4 and 5) or annual (Figures 7 and 8) timescale.

It is well known that SDR tends to be high where channel slopes and valley side slopes are steep (Goudie 2004; Diodato and Grauso 2009). In the Chabagou watershed, upland slopes are generally steeper than $36 \%$. The channel slope decreases to $9 \%-18 \%$ for the smallest streams, and further decreases to $1.7 \%-3.5 \%$ for the tributaries and to $1.4 \%$ for the main stream of the Chabagou Creek. For the Dalihe River and the IR\# 3 Reach of the Wudinghe River, the channel slope is as gentle as $2.6 \%$ and $1.7 \%$, respectively. The fact that SDR remains close to 1 over a wide range of spatial scale and does not decrease with gentler channel can be related with hyper-concentrated flows. The fall velocity of sediment grains in hyper-concentrated flows is reduced by one (Pierson 2005) even two or three (Chien and Wan 1999) orders of magnitude relative to that in clear water. The calculation by Chien and Wan (1999) indicates that inclusion of additional sediment particles would not burden flows any more when sediment concentration exceeds $400 \mathrm{~kg} \mathrm{~m}^{-3}$, a value much smaller than the mean sediment concentration of single events in the Chabagou watershed $\left(680-800 \mathrm{~kg} \mathrm{~m}^{-3}\right.$; see Table 4 in Zheng et al. (2012)).

As a result, hyper-concentrated flows have very strong capacity to carry sediment even in case of low flow strength. It has been well observed in the Loess Plateau that very high concentrations (> $1000 \mathrm{~kg} \mathrm{~m}^{-3}$ ) readily occur at extremely low discharges (See Figure 2 in Zheng et al. (2008)). Likewise, hyper-concentrated flows can travel a distance as long as 100-200 km (Chien et al. 1987; Chien 1989; Fei 1988), with little deposition loss and even the outline of sediment concentration hydrographs remaining almost unchanged (Fei 1988), regardless of the intensive backwater effect upstream of a reservoir (Chien et al. 1987) or the gentle channel gradient (0.2\%o-0.25\%o) (Fei 1988).

As shown in Figure 10, hyper-concentrated flows occur whether at low or at high discharges at station \#12, where the channel gradient was as gentle as $0.25 \%$. Hyper-concentrated flows remain dominant in other first-order tributaries of the middle Yellow River, which has a channel gradient

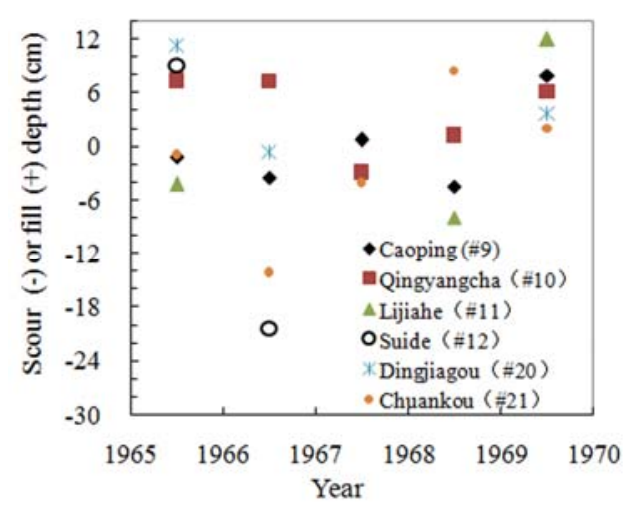

Figure 8 Depth of scour of fill relative to the last preflood season at the six channel cross-section profiles. The measurement dates were given in Figure 7.

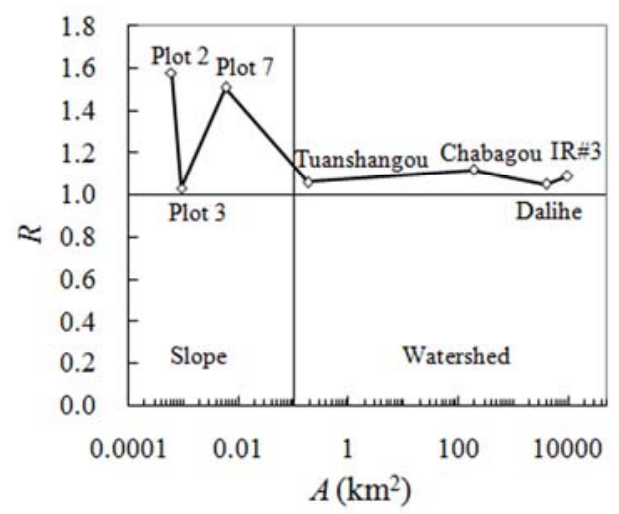

Figure $9 R$ varying from slopes to watersheds, indicating whether sediment deposition occurs at the inter-annual timescale (deposition occurs if $R<1$ ).

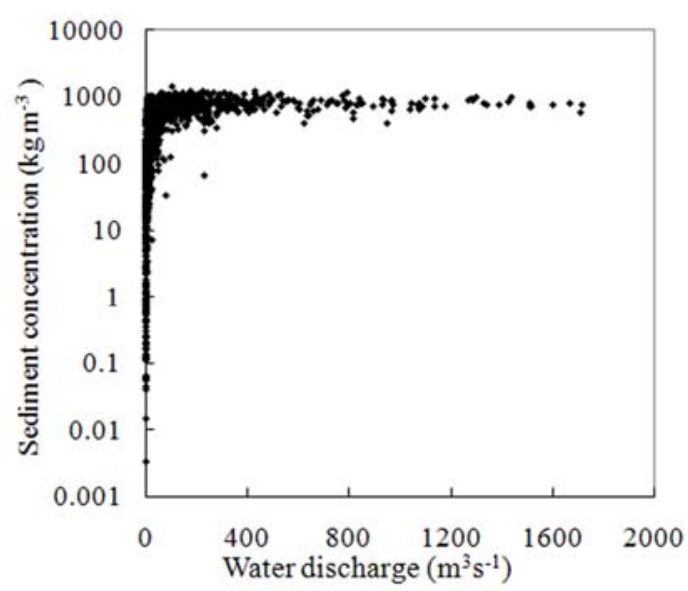

Figure 10 The water discharge-sediment concentration relationship for the Suide station (\#12). Data involve the period from 1959 to 1969.

between $1.5 \%$ and $8.9 \%$. These tributaries are thus likely to have a SDR close to 1 below the interannual timescale.

Sediment deposition on floodplains and other 
sinks is strongly responsible for the decreasing SDR with increasing basin size (de Vente et al. 2007). In the Loess Plateau, floodplains are typically 1-2 meters in thickness and can rarely exceed a dozen of meters in width (Jing et al. 1993). Considering the long time period of the floodplains' development, the vertical accretion in one single year should be very limited (Jing et al. 1993), as demonstrated by Figures 7 and 8 and the field survey in the Wudinghe basin (Xu and Sun 2004). Terraces usually border the stream channel in the Wudinghe basin, but they are commonly at a considerable height above the present channel (above 2-3 $\mathrm{m}$ ) so that the flood inundation rarely occurs. Alluvial fans at the river confluence are also not well developed (Xu and Sun 2004) and do not act as important sediment sink.

\section{Conclusions}

Information on the sediment delivery is scarce at the timescale below the inter-annual timescale, although it has been well known that SDR is close to 1 at the inter-annual timescale in the Chinese Loess Plateau. We evaluated sediment delivery from plots to watersheds at the event or intraannual, annual, and inter-annual timescales, using observations at a series of nested sites within the $30,261 \mathrm{~km}^{2}$ Wudinghe River basin during the period 1959-1969. It was found that sediment deposition rarely occurs except for some small runoff events (sediment yield $<5000 \mathrm{t} \mathrm{km}^{-2}$ ) or dry years (sediment yield $<10,000 \mathrm{t} \mathrm{km}{ }^{-2}$ ) when moving from slopes to channels of various orders;

\section{References}

Alatorre LC, Beguería S, García-Ruiz JM (2010) Regional scale modeling of hillslope sediment delivery: A case study in the Barasona Reservoir watershed (Spain) using WATEM/ SEDEM. Journal of Hydrology 391: 109-123. DOI: 10.1016/ j.jhydrol.2010.07.010

Angulo-Martínez M, Beguería S (2009) Estimating rainfall erosivity from daily precipitation records: a comparison among methods using data from the Ebro Basin (NE Spain). Journal of Hydrology 379: 111-121. DOI: 10.1016/j.jhydrol. 2009.09.051

Cai QG, Wang GP, Chen YZ (1998) Processes of soil erosion and sediment yield and the related simulation for small catchments on the Loess Plateau. Beijing: Science Press. (In Chinese) this suggests a SDR close to 1 at the event or annual timescale, but not necessarily at the inter-annual timescale. We do not find any significant channel degradation or aggradation at the spatio-temporal scales we examined. Such a high SDR can be related to hyper-concentrated flows, which are well developed in the Loess Plateau and can carry a large amount of sediment even at low flow discharges and at gentle channels.

Further work is needed to verify our inference at the event or intra-event timescale, because we only provided observations at three channel crosssection profiles when basin size is larger than 200 $\mathrm{km}^{2}$. It is also desirable to investigate sediment delivery in other rivers of the Loess Plateau at various temporal scales, where hyper-concentrated flows dominate as well and promise to allow a SDR close to 1 at the event or intra-event timescale.

\section{Acknowledgements}

The research is funded by National Natural Science Foundation of China (Grant Nos. 41230746, 41271306), the National Key Technology Research and Development Program (Grant No. 2012BACo9Bo3), and the Open-fund Project of Jiangxi Provincial Key Laboratory of Soil Erosion and Prevention (Grant No. JXSB201301). We appreciate the suggestions of the anonymous reviewers and the editor. Thanks the Data Sharing Infrastructure of Earth System Science-Data Sharing Infrastructure of Loess Plateau (www.geodata.cn) for providing our data.

Chien N (1989) Mechanism of hyperconcentrated flows. Beijing: Tsinghua University Press. (In Chinese)

Chien N, Wan ZH (1999) Mechanics of sediment transport. Reston: ASCE Press.

Chien N, Zhang R, Zhou ZZ (1987) Fluvial process Theory. Beijing: Science Press. (In Chinese)

de Vente J, Poesen J, Arabkhedri M, Verstraeten G (2007) The sediment delivery problem revisited. Progress in Physical Geography 31(2): 155-178. DOI: $10.1177 / 0309133307076485$

Diodato N, Grauso S (2009) An improved correlation model for sediment delivery ratio assessment. Environmental Earth Sciences 59(1): 223-231. DOI: 10.1007/s12665-009-0020-X

Fei XJ (1988) Application and mechanisms for the longdistance travel of hyperconcentrated flows. Journal of 
Sediment Research (3): 55-61. (In Chinese)

Gong SY, Xiong GS (1979) The origin and the regional distribution of sediment of the Yellow River. Yellow River (1): 7-11. (In Chinese)

Gong SY, Xiong GS (1980) The origin and transport of sediment of the Yellow River. Paper presented at Proceedings of the UNESCO International Symposium on River Sedimentation. In: Proceedings of International Conference on River Sediment. Beijing: Guang Hua Press. pp 43-52. (In Chinese)

Gong SY (1988) Characteristics of soil erosion in the Loess Plateau of the Yellow River basin. Soil and water conservation in China (9):8-10. (In Chinese)

Goudie A (2004) Encyclopedia of geomorphology (Vol. 2). London: Routledge. pp 932-933.

Jing K, Cheng YZ, Li FX (1993) Sediment and environment in the Huanghe River. Beijing: Science Press. (In Chinese)

Jing K, Lu JF, Liang JY, et al. (1997) Environment Controls and the Trend of Soil Erosion in the Middle Yellow River, China. Zhengzhou: Yellow River Water Conservancy Press. pp 134136. (In Chinese)

Lane LJ, Hernandez M, Nichols M (1997) Processes controlling sediment yield from watersheds as functions of spatial scale. Environmental Modeling \& Software 12(4): 355-369. DOI: 10.2111/05-075R1.1

Li LJ, Zhang L, Wang H, et al. (2007) Assessing the impact of climate variability and human activities on streamflow from the Wuding River basin in China. Hydrological Processes 21: 3485-3491. DOI: 10.1002/hyp.6485

Liu QJ, Shi ZH, Fang NF, et al. (2013) Modeling the daily suspended sediment concentration in a hyperconcentrated river on the Loess Plateau, China, using the Wavelet-ANN approach. Geomorphology 186: 181-190. DOI: 10.1016/ j.geomorph.2013.01.012

Lu H, Moran CJ, Sivapalan M (2005) A theoretical exploration of catchment-scale sediment delivery. Water Resources Research 41:Wo9415. DOI: 10.1029/2005WRo04018

Marques MJ, Bienes R, Pérez-Rodríguez R, Jiménez L (2008) Soil degradation in Central Spain due to sheet water erosion by low-intensity rainfall events. Earth Surface Processes and Landforms 33: 414-423. DOI: 10.1002/esp.1564

Ministry of Water Resources of the PRC (1962) National Standards for Hydrological Survey of China. Industry Press, Beijing. (In Chinese)

Moliere DR, Evans KG, Saynor MJ, Erskine WD (2004) Estimation of suspended sediment loads in a seasonal stream in the wet-dry tropics, northern Territory, Australia. Hydrological Processes 18: 531-544. DOI: 10.1002/hyp.1336

Mou JZ, Meng QM (1982) Sediment delivery ratio as used in the computation of the watershed sediment yield. Journal of Sediment Research (2): 223-230. (In Chinese)

Notebaert B, Verstraeten G, Rommens T, et al. (2009) Establishing a Holocene sediment budget for the river Dijle. Catena 77: 150-163. DOI: 10.1016/j.catena.2008.02.001

Parsons AJ, Wainwright J, Brazier RE, Powell DM (2006) Is sediment delivery a fallacy? Earth Surface Processes and Landforms 31: 1325-1328. DOI: 10.1002/esp.1395

Pierson TC (2005) Hyperconcentrated flow-transitional process between water flow and debris flow. In: Jakob M, Hungr O (Eds) . Debris-flow Hazards and Related Phenomena. Berlin Heidelberg: Springer. pp 159-201.

Sadeghi SHR, Bashari Seghaleh M, Rangavar AS (2013) Plot Sizes Dependency of Runoff and Sediment Yield Estimates from a Small Watershed. Catena 102:55-61. DOI: 10.1016/ j.catena.2011.01.003

Shi ZH, Cai CF, Ding SW, et al. (2004) Soil conservation planning at the small watershed level using RUSLE with GIS: a case study in the Three Gorge Area of China. Catena 55: 3348. DOI: 10.1016/So341-8162(03)00088-2

Shi ZH, Ai L, Li X, Huang XD, et al. (2013) Partial least-squares regression for linking land-cover patterns to soil erosion and sediment yield in watersheds. Journal of Hydrology 498: 165176. DOI:10.1016/j.jhydrol.2013.06.031

Shi ZH, Huang XD, Ai L, et al. (2014) Quantitative analysis of factors controlling sediment yield in mountainous watersheds. Geomorphology 226: 193-201. DOI:10.1016/j.geomorph.2014. 08.012

Vigiak O, Newham LTH, Roberts AM, et al. (2011) Integrating farming systems and landscape processes to assess management impacts on suspended sediment loads. Environmental Modelling and Software 26: 144-162. DOI: 10.1016/j.envsoft.2010.09.001

Walling DE (1983) The sediment delivery problem. Journal of Hydrology 65(1): 209-237. DOI: 10.1177/0309133307076485.

Walling DE (1999) Linking land use, erosion and sediment yields in river basins. Hydrobiologia 410: 223-240. DOI: 10.1023/A:1003825813091

Wang XK, Chien N, Hui WD (1982) The formation and process of confluence of the flow at hyperconcentration in the gullied-hilly loess areas of the Yellow River Basin. Journal of Hydraulic Engineering (7): 26-35. (In Chinese)

Wischmeier WH, Smith DD (1978) Predicting rainfall erosion losses: a guide to conservation planning, USDA. Agriculture Handbook No. 537, Washington, DC. p46.

Xu JX (1999) Erosion caused by hyperconcentrated flow on the Loess Plateau. Catena 36:1-19. DOI:10.1016/So341-8162(99) 00009-0.

$\mathrm{Xu}$ JX (2004) Hyperconcentrated flows in the slope-channel systems in gullied hilly areas on the Loess Plateau, China. Geografiska Annaler: Series A, Physical Geography 86A (4): 349-366. DOI:10.1111/j.0435-3676.2004.00237.x.

Xu JX, Sun J (2004) Effect of erosion control measures on sediment delivery ratio. Journal of Hydraulic Engineering 15(1): 30-34. (In Chinese)

Xu JX, Yan YX (2005) Scale effects on specific sediment yield in the Yellow River basin and geomorphological explanations. Journal of Hydrology 307: 219-232. DOI:10.1016/j.jhydrol. 2004.10.011.

$\mathrm{Xu}$ JX (2011) Variation in annual runoff of the Wudinghe River as influenced by climate change and human activity. Quaternary International 44: 230-237. DOI: 10.1016/j.quaint. 2010.09.014.

Zhang HX (1983) The characteristics of hard rain and its distribution over the loess plateau. Acta Geographica Sinica 38 (4): 416-425. (In Chinese)

Zheng MG, Cai QG, Cheng QJ (2008) Modelling the runoffsediment yield relationship using a proportional function in hilly areas of the Loess Plateau, North China. Geomorphology 93: 288-301. DOI: 10.1016/j.geomorph.2007.03.001

Zheng MG, Qin F, Sun LY, et al. (2011) Spatial scale effects on sediment concentration in runoff during flood events for hilly areas of the Loess Plateau, China. Earth Surface Processes and Landforms 3: 1499-1509. DOI: 10.1002/esp.2176

Zheng MG, Yang JS, Qi DL, et al. (2012) Flow-sediment relationship as functions of spatial and temporal scales in hilly areas of the Chinese Loess Plateau. Catena 98: 29-40.

Zheng MG, Qin F, Yang JS, et al. (2013) The spatio-temporal invariability of sediment concentration and the flow-sediment relationship for hilly areas of the Chinese Loess Plateau. Catena 109: 164-176. 